\title{
Technological and Pedagogical Models: Analysis of Factors and Measurement of Learning Outcomes in Education
}

\author{
Ratnawati Susanto ${ }^{1}$ \\ Universitas Esa Unggul, Jakarta, Indonesia \\ Reza Rachmadtullah \\ Universitas PGRI Adi Buana, Surabaya, Indonesia \\ Widarto Rachbini \\ Graduate School Universitas Pancasila, Jakarta, Indonesia
}

\begin{abstract}
The era of the industrial revolution 4.0 emphasizes the importance of the digital literacy elaboration that links the full technological and pedagogical capabilities to enhance learning outcomes in all three domains that include knowledge, skills and attitudes. Much is needed of factor analysis and measurement studies that touch on aspects of pedagogy and technology as an indicator analysis of pedagogical competency development models. The method used is a quantitative approach, data analysis technique is done through the Goodness of-Fit criteria. The stages of modeling and analysis of structural equations in the analysis of first and second measurement models are performed with CFA and using SEM as a tool. Data analysis was also carried out to analyze indicators that predominantly influenced learning outcomes. The results of the study concluded that the Technological and Pedagogical Model was a factor and measurement of learning achievements in education.
\end{abstract}

Keywords: Technological, Pedagogical, Learning Outcome.

\section{Introduction}

The world of education in the era of the industrial revolution 4.0 emphasized the importance of digital literacy (Tamte, Enochsson, Buskqvist, and Kårstein, 2015). The colors of education unite the application of pedagogy and ICT (Rienties et al., 2013). That need is seen in the interaction of education that unites educators with ICT (Barak, 2017). So pedagogy and technology are a unified whole in the development model of pedagogical competence (He, Lundgren, \& Pynes, 2017; Mei, Lin, Wang, \& Lin, 2010). This reflects the fact that education and ICT become policies and learning principles that need to be designed and applied in the world of education (Lucke, Dunn, and Christie, 2017; Sumantri, Prayuningtyas, Rachmadtullah, and Magdalena, 2018). This indicates that there is an ICT focus as educator competencies in the world of education and knowledge-based learning models (Applewhite, Kao, \& Pritzker, 2018). Educators really need to have ICT-based classroom management skills (Computers, 2013). Then the competence of educators is a competency based on technological, pedagogical and knowledge competencies (Sergis, 2014) .

Naturally there will also be a change in measurement, which is a measurement that uses a new ICT-based paradigm (Redecker, 2013). In this new paradigm, educators need to become educators who are experts in content, technology and communication (Uerz, Volman, \& Kral, 2018). Educators are musicians in classroom management based on communicative interactions (Angeli \& Valanides, 2005) The ability of educators in knowledge, in establishing educational

\footnotetext{
${ }^{1}$ Correspondence Author E-Mail : ratnawati@esaunggul.ac.id
} 
interactions, digital literacy skills or ICT and educational communication skills need to be built for the development of learners and build positive, reflection, critical and evaluative views. (Livingstone, 2007). So the mastery of technology, pedagogy, knowledge content and communication is a factor and measurement model of pedagogical competency development based on Technological, Pedagogical and Knowledge content (TPACK) (Rosenberg \& Koehler, 2015) and this ability becomes a strategy \& key to educational success (Koh \& Chai, 2016; Rachmadtullah, Ms, \& Sumantri, 2018).

The successful mastery of technology in learning includes how the ability of educators to use technology in preparing learning tools, in implementing learning, in assessing and facilitating students in accessing learning devices, getting information and feedback on assessments and ease of access (Liu, Tsai, \& Huang, 2015; Woofter, 2019). The ability to master technology and application in learning to overcome difficulties and obstacles in learning, overcome problems of limited space and time, overcome differences in characteristics, learning styles and can do repetition of learning incomprehension and incompleteness (Devine, et al, 2013) The ability to apply technology in learning can also improve learning attitudes and behavior and independent learning tendencies and encourage learning to construct knowledge (Andrew et al.,2018; Halpern, 2017). The ability to master the application of technology will be able to improve the professionalism of educators in achieving learning outcomes (Chi \& Wylie, 2014). But the use of technology or ICT in learning is also not easy and without obstacles if educators do not have a strong desire to use technology as a key to successful learning, have limited self-confidence, low technological competence and unavailability of networks or technological infrastructure (Jin, 2019). So the development and use of technology is integrated in all human life and education is no exception (Yousafzai, Chang, Gani, \& Noor, 2016). In the field of education, the use of technology focused on achieving learning and technological achievements is perceived as the availability of infrastructure and internet and intranet networks, ICT capabilities and the strong desire of educators to integrate ICT in learning (McFarlane, 2019).

The preparation of pedagogical competencies is very basic for the teaching profession (Wahyudin, 2016) Previous research states that pedagogical competence is a manifestation of learning interactions. Pedagogical competence guarantees the focus of the learner, the level of service, the value contained in the interaction between educators and learners, the ability to listen with positive words, patterns of guidance, and how learning by providing learning experiences for students to develop their potential (Susanto, Rozali, and Agustina, 2019) Pedagogic or pedagogical abilities include how educators are able to condition collaborative learning and social learning. (social learning).

Collaborative learning (Collaborative Learning) is a learning process that emphasizes the process of collaboration between more than an individual who emphasizes the profile of learners with the use of communication and information technology (Martín-Gutiérrez, Fabiani, Benesova, Meneses, \& Mora, 2015) In previous studies the implementation of collaborative learning increases interactions between learners, improves the quality of learning and face-toface interaction or online learning that uses technology (Alamri \& Tyler-Wood, 2017). This learning process is also a strategy for learning achievement (Iasha, Rachmadtullah, Sudrajat, \& Hartanti, 2019). The process of collaborative learning is a group learning process where each member contributes information, information, experience, ideas, attitudes, opinions, abilities and skills they have to jointly increase the understanding of all members (Turgut, Tunga, \& Kisla, 2016; Yong, Gates, \& Chan, 2019). Collaborative Learning is based on the idea that learning activities should encourage and assist students in the process of building knowledge so as to achieve deep understanding (Jaleel \& Verghis, 2015). can also improve and develop ways. By studying in groups, in addition to increasing student motivation and interest, it can also improve and develop creative thinking. This is part of the professionalism and commitment of educators (Asri et al, 2019; Ollila \& Macy, 2018). 
Social learning (social learning) emphasizes the environment by involving the ability to selectively observe the behavior of other individuals, in other words learning by modeling (Piquero, 2015). Research conducted by Terrell describes that social learning links personal formation and collaboration as achievements of learning.(Chen, Wang, Kirschner, \& Tsai, 2018). Pedagogical abilities effectively impact social learning conditions (Cundill \& Rodela, 2012; Widyasari et al., 2019) Social learning emphasizes the existence of groups and how interactions between educators and learners take place in social and pedagogical interactions (Susanto \& Rachmadtullah, 2019).

Learning achievements expressed in a statement that can be a measurement of what learners should know and understand, or referred to as an ability that can be done, a value or outcome after gaining understanding and learning experience. Learning outcomes are very beneficial for educators. Learning outcomes allow educators to design programs effectively, as a measure of effective learning, and increase learning experiences (Rienties et al., 2013). According to Bloom, effective learning outcomes can be measured in the realm of knowledge levels, skill levels and behavior or attitudes (Rienties et al., 2013).

Technology is related to the teaching and learning process as an effective and efficient media in the teaching and learning process. As a learning medium, technology, especially ICT is associated with various activities used to access, collect, manipulate, and present or communicate information. The intended technology includes equipment (such as computers, laptops, and other devices), software applications and series (for example internet, wifi, local network infrastructure (local network infrastructure and teleconference). The use of technology as a learning medium will obviously make teaching and learning process become effective and efficient because it can facilitate a teacher in obtaining or conveying information (messages or content, material) lessons, can help increase student understanding, presentation of data / information more interesting or reliable, facilitate interpretation of data, and obtain information, so in this case can it is said that technology as a medium is an important role as an effective and efficient tool in the teaching and learning process

This research is very important to do because of the full technological and pedagogical abilities to enhance learning outcomes in all three areas which include knowledge, skills and attitudes. The results of research conducted by Malik, Rohendi and Widiaty ( 2019) and McKenneyand Visscher (2019), The role of teachers is also needed in the development of information technology in the learning process in schools, technology makes it easy for teachers to convey messages and teachers can develop their pedagogical potential with the help of technology. Wegerif and Major (2019) Technology has begun to be applied in education because of the view that science is believed to improve the quality of human life. Various kinds of technology products that can be utilized in learning show that the presence of information and communication technology products is a necessity in education, especially in learning in the present and future (Beckman, 2018; Wang et al, 2018) The increasing tendency of many people towards ICT is directly related to the increasing stage of computer literacy, information literacy, and also increasing community welfare. These factors complement each other and cannot be separated. People who live in developed countries show a tendency for higher public literacy compared to people in developing and poor countries. The integration of information and communication technology in education develops through three stages, namely the use of Audio-Visual Aid, the use of programmed material. The use of computers in education (Cahyana, Sumantri, \& Hasanah, 2017; Hadar \& Ergas, 2019; Jandrić et al., 2018). Based on the research findings that have been presented, the results of the study are useful to inform that the importance of the study of factor analysis and measurement that touches on aspects of pedagogy and technology as an indicator analysis of pedagogical competency development models. This research is expected to be able to provide solutions for the advancement of education through aspects of pedagogy and technology, especially in Indonesia and for 
countries outside Indonesia, which are expected to be able to influence the advancement of technology for teachers.

\section{Literature Review}

\section{Technological}

Globally, information and communication technology are all aspects that involve technology, engineering, and management techniques used in controlling and processing information and its use (Lawrence \& Tar, 2018). There are three main components of learning based on information and communication technology namely computers, multimedia, and telecommunications. In addition, information and communication technology is also an inseparable state that contains a broad understanding of all activities related to processing, manipulation, management, and transfer of information between media. Technology is something that cannot be avoided in this life, because technological progress will go according to the progress of science (Khanagha, Ramezan Zadeh, Mihalache, \& Volberda, 2018). Every innovation created to provide benefits to human life, provide many conveniences, and as a new way of doing human activities, specifically in the field of technology, people have enjoyed many benefits brought about by the innovations that have been produced. Information and Communication Technology, is a large umbrella terminology that includes all technical equipment for processing and delivering information. ICT covers two aspects, namely information technology and communication technology. Information technology includes all matters relating to the process, use as a tool, manipulation, and management of information. While communication technology is everything related to the use of tools to process and transfer data from one device to another. Therefore, information technology and communication technology are two inseparable concepts. So Information and Communication Technology contains a broad understanding that is all activities related to processing, manipulation, management, transfer of information between media (Alluhaidan, Chatterjee, Drew, \& Stibe, 2018).

\section{Pedagogical}

Pedagogical is a combination of special abilities of content and pedagogical knowledge that is formed over time and increasing teaching experience (Gess-Newsome et al., 2019). Pedagogical has been accepted as an academic construct that connects several variables with the teacher's basic professional knowledge. Pedagogical academic constructs are identifiers that teaching is not just a transfer of knowledge and skills from teachers to students, but is more complex than that because it includes complex activities and requires various decisions and responses to students' learning needs. Good pedagogical is synonymous with effective teacher. However, effective teachers are not born, but are formed through a series of processes and a long time to get the skills and knowledge needed to become professional teachers in their fields (Daane et al, 2018).

\section{Methods}

\section{Research Design}

This study aims to determine the factors and measurements that touch on aspects of pedagogy and technology as an indicator analysis of pedagogical competency development models. The method used in this research is a quantitative approach with associative design while the design of the model in this study can be seen in Figure 1: 


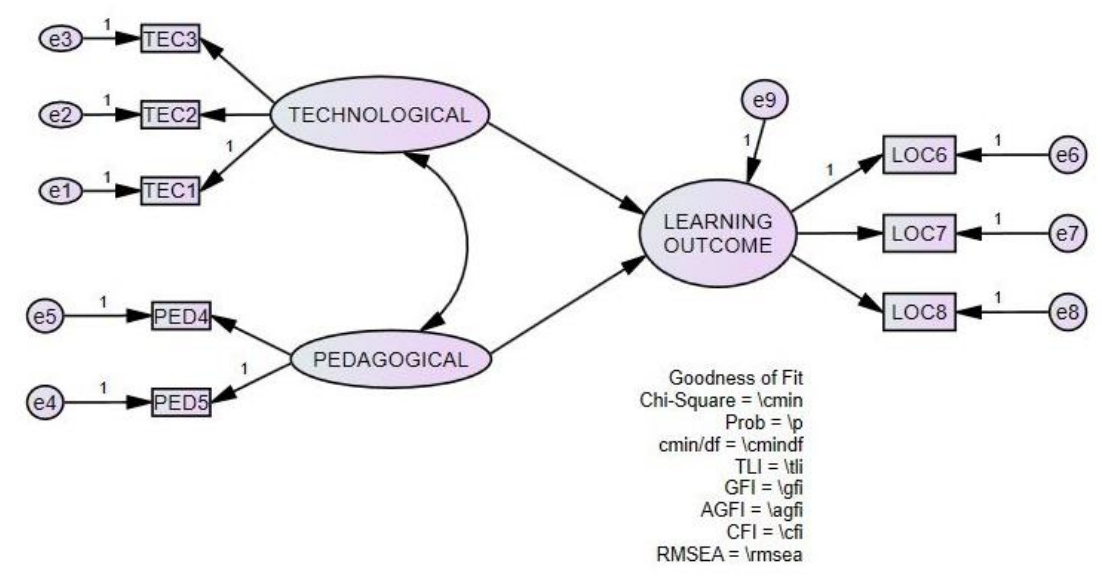

Figure 1. Technological, Pedagogical Model and Learning Outcome

Structural equation model path diagram:

LOC $=\beta$ TEC + z 1 (1)

$\mathrm{LOC}=\beta$ PED $+\mathrm{z} 2$ (2)

Information:

TEC $=$ Technological

PED = Pedagogical

LOC = Learning outcome

Research Hypothesis:

H1: The higher the technological capability, the higher the learning achievement

$\mathrm{H} 2$ : The higher the pedagogical ability, the higher the learning achievement.

H3: There are dominant indicators in influencing the high level of achievement

Learning.

\section{Definition of Variable Operations}

Technological is the level of teacher's ability to utilize the availability of infrastructure and internet and intranet networks, ICT ability and the strong desire of educators to integrate ICT in learning. Pedagogical is the level of educator's ability to condition collaborative learning and social learning. Learning outcome is an ability that can be done, a value or an outcome after gaining understanding and learning experience and showing the level of ability in the realm of knowledge, skills and attitudes.

\section{Data Collection Technique}

Data collection was carried out using a questionnaire instrument consisting of 8 question items that explored information and data regarding the ability of teachers in technoligcal and pedagogical as well as learning outcomes obtained. The questionnaire was made with a Likert scale consisting of 5 answer choices with very high measurements (score 5), high (score 4), high enough (score 3), low (score 2), very low (score 1). Data was collected from the population of educators in elementary schools in Region II of the West Jakarta City Administration, West Jakarta, which includes Duri Kepa, Kedoya and Grogol Petamburan districts with a sample size of 250 assuming the Maximum Likelihood Estimation Model (EML) that recommends sample sizes between 100-200. 


\section{Data Analysis Technique}

Data analysis techniques to identify the influence of the level of technological, and pedagogical abilities on learning outcomes are carried out to get constructor analysis indicators that can be used as models for the development of learning outcomes. Data analysis technique is done through Goodness of-Fit (GoF) criteria. Stages of modeling and analysis of structural equations for first and second model analysis. Measurements were made with Confirmatory factor analysis (CFA) and using Structural equation modeling (SEM) as a tool. Data analysis was also carried out to analyze indicators that predominantly influenced learning outcomes.

\section{Results}

\section{Construct Validity}

The construct validity test shows the indicator size reflects the theoretical latent construct through Confirmatory Factor Analysis (CFA) with the following table 1:

Table 1

Construct Validity

\begin{tabular}{llc}
\hline & & Estimate \\
\hline Learning outcome & Technological & 653 \\
Learning outcome & Pedagogical & 976 \\
Tec1 & Technological & 717 \\
Tec2 & Technological & 659 \\
Tec3 & Technological & 696 \\
Tec4 & Pedagogical & 750 \\
Tec5 & Pedagogical & 800 \\
Tec6 & Learning outcome & 725 \\
Tec7 & Learning outcome & 761 \\
Tec8 & Learning outcome & 709 \\
\hline
\end{tabular}

The standardized regression values in the table indicate the loading factor of each indicator to the construct where all values are $>0.60$, which means the indicators are valid as indicators to measure the construct

\section{Constructive Reliability}

The construct reliability test can be shown in the following table.

\section{Table 2}

Constructive Reliability

\begin{tabular}{lcc}
\hline & Cronbach's Alpha & N of Items \\
\hline Technological & .732 & 3 \\
Pedagogical & .751 & 2 \\
Learning outcome & .776 & 3 \\
\hline
\end{tabular}

The calculation results show that all instruments have very high reliability figures (Cronbach's Alpha), because according to Nunnaly (1967) (Peterson, 1994) and Hinkle (2004) (A. Wheelan, 2004) or an index commonly used in social research, if the Cronbach's Alpha $(\alpha)$ number above 0.60 indicates that the construct or variable is reliable. 


\section{Model Goodness of Fit}

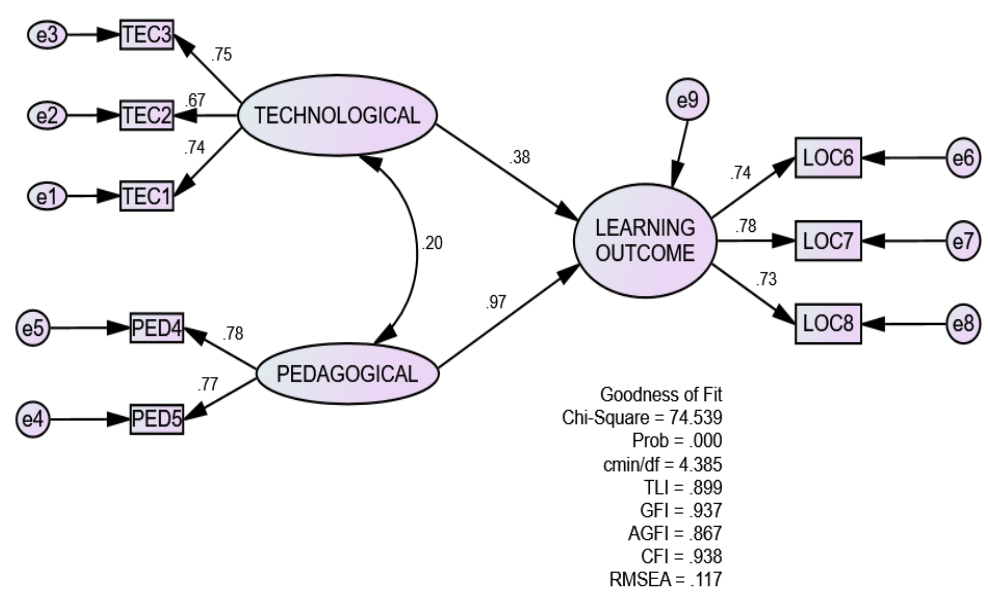

Figure 2. Model Goodness of Fit (GOF)

The diagram above provides summary information of GOF test results on the research model that can be presented in the following table data.

Table 3

Goodness-of-fit Model

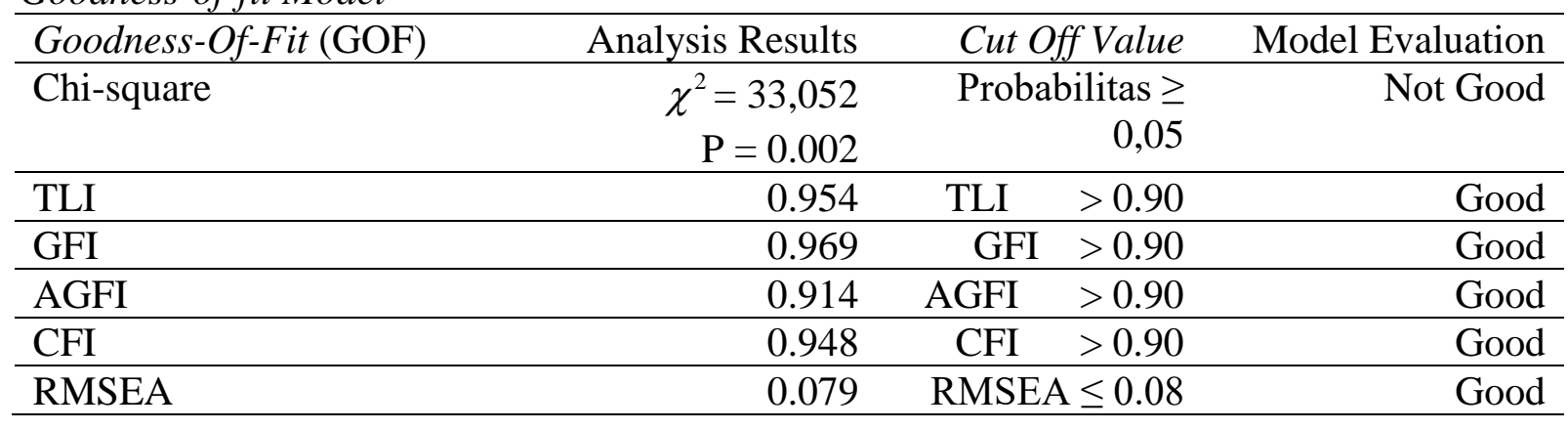

The table above provides summary information of GOF (Goodness of Fit) test results on the research model as follows: (1) the chi-square criteria 33,052> 0.05 shows less good because the smaller the better the better, (2) Model fit test with TIJ 0.954>0.90 shows good results, (3) GFI 0.969>0.90 shows good results, (4) AGFI 0.914>0.90 so that the model can be accepted as a good model, (5) CFI 0.948> 0.90 shows good results, (6) RMSEA analysis as an index to compensate for chi Square statistics shows $0.079 \leq 0.08$ so that there is a fit of the model with the data so that the model can be accepted, then based on the existing GOF criteria, the GOF is fulfilled, it is concluded that the model is fit with the data.

\section{Hypothesis Testing}

Hypothesis testing is done with the criteria of Critical Ratio (CR)> 1.96 or the value of Probability $(\mathrm{P})<0.05$ then the basis for decision making:

If the probability value ( ig value) $>0.05$ or $-\mathrm{t}$ table $<\mathrm{t}$ count $<\mathrm{t}$ table then $\mathrm{H} 0$ is not rejected If the probability value (sig value) $<0.05$ or $\mathrm{t}$ arithmetic $<-\mathrm{t}$ table or $\mathrm{t}$ arithmetic $>\mathrm{t}$ table then $\mathrm{H} 0$ is rejected 
Table 4

Goodness-of-fitmodel

\begin{tabular}{llrr}
\hline & & Estimate & S.E \\
\hline Learning outcome & Technological & 362 & 064 \\
Learning outcome & Pedagogical & 719 & 062 \\
Tec1 & Technological & 1000 & \\
Tec2 & Technological & 910 & 111 \\
Tec3 & Technological & 922 & 104 \\
Tec4 & Pedagogical & 1000 & \\
Tec5 & Pedagogical & 833 & 062 \\
Tec6 & Learning outcome & 1000 & \\
Tec7 & Learning outcome & 1020 & 082 \\
Tec8 & Learning outcome & 994 & 078 \\
\hline
\end{tabular}

Thus the structural equation is:

1. Learning outcome $=0.362 *$ technological $+\mathrm{e}$

2. Learning outcome $=0.719 *$ pedagogical $+\mathrm{e}$

The value of $\mathrm{p}=* * *$ (meaning the value is below 0.001 , so this is significant at the 0.01 level which is certainly better than the 0.05 level)

\section{Hypothesis Testing}

Decision:

1. $\mathrm{p}$-value of the Technological variable $=* * *<0.05$ so H0 is rejected and H1 is accepted, which means that the Technological variable has a positive and significant effect on the Learning outcome variable.

2. $\mathrm{P}$-value of Pedagogical variable $=* * *<0.05$ so $\mathrm{H} 0$ is rejected and $\mathrm{H} 1$ is accepted, which means Pedagogical variable has positive and significant effect on Learning Outcome variable.

\section{Indicator of the Dominant Variable in the Learning Model}

Of the eight indicators on the three research variables (in table 3) all meet the significance due to loading factor $>0,05$ and can be described as the dominant variable indicator of the research model as follows.

1. In technological variables with 3 indicators have a dominant indicator on:

a) Tec 1 on scale 1 which means exceeding loading factor (>) 0,700, which means that absolutely necessary indicators of the availability of infrastructure and internet and intranet networks that are used by educators.

b) Tec 3 at a magnitude of 0.922 means it exceeds the loading factor $(>)$ of 0.700 , meaning that it is absolutely necessary to have an indicator of the strong desire of educators to integrate ICT into learning.

c) Tec 2 at the amount of 0.910 which means it exceeds the loading factor (>) 0,700, which means that it is absolutely necessary indicators of ICT ability of educators.

2. In pedagogical variables with 2 indicators have dominant indicators on:

a) Ped 5 on the scale of 1 which means exceeding the loading factor (>) 0,700, which means that absolutely necessary indicators of the ability level of educators in conditioning collaborative learning (collaborative learning). 
b) Ped 4 at a magnitude of 0.833 which means exceeding the loading factor (>) 0,700, which means that absolutely necessary indicators of the level of the ability of educators in conditioning social learning (Social learning).

3. In the Learning Outcome variable, Technological or Pedagogical influences provide data that:
a) The high effect is found in Loc 7 at 1.020 which exceeds the loading factor (>0.07), meaning that the effect is very high in the impact on the outcome of learning skills.
b) In Loc 6 at a magnitude of 1,000 that exceeds the loading factor (>0.07), it means that a very high effect also has an impact on learning outcomes of knowledge.
c) In Loc 8 at a magnitude of 0.994 that exceeds the loading factor (>0.07), it means that a very high effect is also found on attainment learning outcomes.

\section{Discussion and Conclusion}

Based on the results of the terms that have been described, there is technological progress as now, educators must be able to anticipate changes, so as not to miss the rapid sophistication of technology. The use of information technology in teaching and learning activities appropriately is expected to be able to make the learning process more meaningful, given the various potential of information technology to support teaching and learning activities. With the presence of technology, there is no other choice for the world of education than taking part in utilizing it, which now allows for a wider communication process. Teachers follow the development of technology, it will be easier to understand the progress of technology that is so very fast development, on the contrary, teachers do not become technology illiterate towards the advancement of sophisticated technology. This is in line with the basic theory and framework of thinking formulated by Chi MTH, Wylie R The ability to master the application of technology will be able to improve the professionalism of educators in achieving learning outcomes (Chi \& Wylie, 2014; Karakus, 2018). The results of the study also reinforce the theoretical basis proposed by Terrell that social learning links personal formation and collaboration as learning outcomes (Reed et al., 2010). The results of learning outcome that are formed on the ability of Technological and Pedagogical provide construction on learning outcome of knowledge, skills and attitudes positively and significantly (Rienties et al., 2013; Zare, 2018).

The findings of this study also have a positive impact on teachers' knowledge of the use of technology, because technology makes it easy for teachers to deliver messages to their students. Furthermore, by using technology, the teacher will be greatly helped in carrying out their duties in teaching. namely their learning will be more interesting so that it will be able to foster student motivation in participating in learning from the teacher. Visualization and animation of subject matter will make students easier to understand and more interested in deeper learning the material. If all learning material can be packaged in a laptop then it is the same as carrying the world in one hand. Imagine how much information can be entered on the laptop and displayed by the teacher to his student students. Even various dictionaries and encyclopedias can be embedded in the laptop as a source of learning that has extraordinary capacity.

Learning by utilizing technology has a positive impact on learning that is more relevant to the real world because the material on the laptop is the latest material and can always be updated. Thus, the teacher and students can do the teaching and learning process with the latest material and will not miss the material from any part of the world. The teacher can arrange the material according to students' needs for real life.

Clear learning will be more contextual and meaningful. Teachers and students will learn from each other on material that has a relationship with the real world. Teachers will also be 
more motivated and challenged to look for other learning resources so that they will encourage them to be more active and creative.

Learning to use technology will encourage teachers to be able to create their own materials by trying to perfect the materials that are already in their laptops. Thus, the teachers will need cooperation with other teachers in adjusting existing material to their real needs in class. This will encourage the realization of the principle of lifelong learning or because the teacher will be challenged to always look for material from any source he can dig. Technological and Pedagogical Models are factors and measurements of learning outcome in education. This is evidenced by the results of research that concludes and answers the research hypothesis that the higher technological capability, the higher performance learning. The higher the pedagogical ability, the higher the learning outcome. There are dominant indicators in influencing high levels of learning outcome.

\section{Acknowledgements}

The authors would like to thank all those who have contributed participation in this study.

\section{References}

Alamri, A., and Tyler-Wood, T. (2017). Factors Affecting Learners With DisabilitiesInstructor Interaction in Online Learning. Journal of Special Education Technology, 32(2), 59-69. https://doi.org/10.1177/0162643416681497

Alluhaidan, A., Chatterjee, S., Drew, D., \& Stibe, A. (2018). Sustaining Health Behaviors Through Empowerment: A Deductive Theoretical Model of Behavior Change Based on Information and Communication Technology (ICT). https://doi.org/10.1007/978-3-31978978-1_3

Andrew, M., Taylorson, J., Langille, D. J., Grange, A., \& Williams, N. (2018). Student attitudes towards technology and their preferences for learning tools/devices at two universities in the UAE. Journal of Information Technology Education: Research, 17, 309-344. https://doi.org/10.28945/4111

Angeli, C., \& Valanides, N. (2005). Preservice elementary teachers as information and communication technology designers : an instructional systems design model based on an expanded view of pedagogical content knowledge. Journal of Computer Assisted Learning, 21(4), 292-302.

Applewhite, S. R., Kao, D., \& Pritzker, S. (2018). Educator and practitioner views of professional competencies for macro social work practice. International Social Work, 61(6), 1169-1186. https://doi.org/10.1177/0020872817702705

Asri Humaira, M., Rasmitadila, Widyasari, Rachmadtullah, R., \& Kardaya, D. (2019). Using blended learning model (BLM) in the instructional process: teacher student perception's. Journal of Physics: Conference Series, 1175, 012213. https://doi.org/10.1088/1742-6596/1175/1/012213

Barak, M. (2017). Science Teacher Education in the Twenty-First Century: a Pedagogical Framework for Technology-Integrated Social Constructivism. Research in Science Education, 47(2), 283-303. https://doi.org/10.1007/s11165-015-9501-y

Beckman, K., Apps, T., Bennett, S., \& Lockyer, L. (2018). Conceptualising technology practice in education using Bourdieu's sociology. Learning, Media and Technology, 43(2), 197210. https://doi.org/10.1080/17439884.2018.1462205

Cahyana, U., Sumantri, M. S., \& Hasanah, U. (2017, May). Influence model of learning and critical-thinking ability of learning science of primary school students. Proceedings of the 29th International Business Information Management Association Conference - 
Education Excellence and Innovation Management through Vision 2020: From Regional Development Sustainability to Global Economic Growth. Vienna, Austuria

Chen, J., Wang, M., Kirschner, P. A., \& Tsai, C.-C. (2018). The Role of Collaboration, Computer Use, Learning Environments, and Supporting Strategies in CSCL: A MetaAnalysis. Review of Educational Research, 88(6), 799-843. https://doi.org/10.3102/0034654318791584

Chi, M. T. H., \& Wylie, R. (2014). The ICAP Framework : Linking Cognitive Engagement to Active Learning Outcomes. Educational Psychology, 49(4), 219-243. https://doi.org/10.1080/00461520.2014.965823

Computers, J. (2013). Developing a typology of teacher beliefs and practices concerning classroom use of ICT. Journal Computers and Education, 68, 380-387.

Cundill, G., \& Rodela, R. (2012). A review of assertions about the processes and outcomes of social learning in natural resource management. Journal of Environmental Management, 113(September), 7-14. https://doi.org/10.1016/j.jenvman.2012.08.021

Daane, A. R., Haglund, J., Robertson, A. D., Close, H. G., \& Scherr, R. E. (2018). The pedagogical value of conceptual metaphor for secondary science teachers. Science Education, 102(5), 1051-1076. https://doi.org/10.1002/sce.21451

Devine, M., Houssemand, C., \& Meyers, R. (2013). Instructional coaching for teachers : A strategy to implement new practices in the classrooms. Procedia - Social and Behavioral Sciences, 93(1), 1126-1130. https://doi.org/10.1016/j.sbspro.2013.10.001

Gess-Newsome, J., Taylor, J. A., Carlson, J., Gardner, A. L., Wilson, C. D., \& Stuhlsatz, M. A. M. (2019). Teacher pedagogical content knowledge, practice, and student achievement. International Journal of Science Education, 41(7), 944-963. https://doi.org/10.1080/09500693.2016.1265158

Hadar, L. L., \& Ergas, O. (2019). Cultivating mindfulness through technology in higher education: a Buberian perspective. AI and SOCIETY, 34(1), 99-107. https://doi.org/10.1007/s00146-018-0794-z

Halpern, C. (2017). Book Review: In search of understanding: The case for constructivist classrooms (2nd ed.). American Journal of Qualitative Research, 1(1), 32-36.

He, Y., Lundgren, K., \& Pynes, P. (2017). Impact of short-term study abroad program: Inservice teachers' development of intercultural competence and pedagogical beliefs. Teaching and Teacher Education, 66, 147-157. https://doi.org/10.1016/j.tate.2017.04.012

Iasha, V., Rachmadtullah, R., Sudrajat, A., \& Hartanti, D. (2019). The Impact Interactive Learning Media on The Learning Outcomes of Fifth Grade Social Science Knowledge in Elementary Schools. Proceedings of the First International Conference on Technology and Educational Science. https://doi.org/10.4108/eai.21-11-2018.2282120

Jaleel, S., \& Verghis, A. M. (2015). Knowledge Creation in Constructivist Learning. 3(1), 812. https://doi.org/10.13189/ujer.2015.030102

Jandrić, P., Knox, J., Besley, T., Ryberg, T., Suoranta, J., \& Hayes, S. (2018). Postdigital science and education. Educational Philosophy and Theory, 50(10), 893-899. https://doi.org/10.1080/00131857.2018.1454000

Jin, B. (2019). Country-level technological disparities, market feedback, and scientists' choice of technologies. Research Policy, 48(1), 385-400. https://doi.org/10.1016/j.respol.2018.09.007

Karakus, M. (2018). The Moderating Effect of Gender on the Relationships between Age, Ethical Leadership, and Organizational Commitment. Journal of Ethnic and Cultural Studies, 5(1), 74-84.

Khanagha, S., Ramezan Zadeh, M. T., Mihalache, O. R., \& Volberda, H. W. (2018). Embracing Bewilderment: Responding to Technological Disruption in Heterogeneous Market Environments. Journal of Management Studies, 55(7), 1079-1121. https://doi.org/10.1111/joms.12348 
Koh, J. H. L., \& Chai, C. S. (2016). Seven design frames that teachers use when considering technological pedagogical content knowledge (TPACK). Computers and Education, 102, 244-257. https://doi.org/10.1016/j.compedu.2016.09.003

Lawrence, J. E., \& Tar, U. A. (2018). Factors that influence teachers' adoption and integration of ICT in teaching/learning process. Educational Media International, 55(1), 79-105. https://doi.org/10.1080/09523987.2018.1439712

Liu, S., Tsai, H., \& Huang, Y. (2015). Collaborative Professional Development of Mentor Teachers and Pre-Service Teachers in Relation to Technology Integration. Educational Technology and Society, 18(3), 161-172.

Livingstone, S. (2007). How student teachers develop their understanding of teaching using ICT People also read Critical reflections on the benefits of ICT in education.

Lucke, T., Dunn, P. K., \& Christie, M. (2017). Activating learning in engineering education using ICT and the concept of 'Flipping the classroom.' European Journal of Engineering Education, 42(1), 45-57. https://doi.org/10.1080/03043797.2016.1201460

Malik, S., Rohendi, D., \& Widiaty, I. (2019). Technological Pedagogical Content Knowledge (TPACK) with Information and Communication Technology (ICT) Integration: A Literature Review. Proceedings of the 5th UPI International Conference on Technical and Vocational Education and Training (ICTVET 2018). https://doi.org/10.2991/ictvet18.2019.114

Martín-Gutiérrez, J., Fabiani, P., Benesova, W., Meneses, M. D., \& Mora, C. E. (2015). Augmented reality to promote collaborative and autonomous learning in higher education. Computers in Human Behavior, 51, 752-761. https://doi.org/10.1016/j.chb.2014.11.093

McFarlane, A. E. (2019). Devices and desires: Competing visions of a good education in the digital age. British Journal of Educational Technology, 50(3), 1125-1136. https://doi.org/10.1111/bjet.12764

McKenney, S., \& Visscher, A. J. (2019). Technology for teacher learning and performance. Technology, Pedagogy and Education, 28(2), 129-132. https://doi.org/10.1080/1475939X.2019.1600859

Mei, J., Lin, C., Wang, P. Y., \& Lin, I. C. (2010). Pedagogy - technology : A two - dimensional model for teachers' ICT integration. British Journal of Educational Technology, 43(1), 97-108.

Ollila, J., \& Macy, M. (2018). Social studies curriculum integration in elementary classrooms: A case study on a Pennsylvania Rural School. The Journal of Social Studies Research. https://doi.org/https://doi.org/10.1016/j.jssr.2018.02.001

Peterson, R. A. (1994). Linked references are available on JSTOR for this article: A Metaanalysis of Cronbach', s Coefficient Alpha. Oxford Journals, 21(2), 381-391. https://doi.org/10.1086/209405

Piquero, A. R. (Ed.). (2015). The Handbook of Criminological Theory. https://doi.org/10.1002/9781118512449

Rachmadtullah, R., Ms, Z., \& Sumantri, M. S. (2018). Development of computer - based interactive multimedia: study on learning in elementary education. International Journal of Engineering and Technology(UAE), 7(4), 2035-2038. https://doi.org/10.14419/ijet.v7i4.16384

Redecker, C. (2013). Changing Assessment - Towards a New Assessment Paradigm Using ICT. (February).

Reed, M. S., Evely, A. C., Cundill, G., Fazey, I., Glass, J., Laing, A., ... Stringer, L. C. (2010). What is social learning? Ecology and Society, 15(4). https://doi.org/10.5751/ES-03564$1504 \mathrm{r} 01$

Rienties, B., Brouwer, N., Bohle Carbonell, K., Townsend, D., Rozendal, A. P., van der Loo, J., Lygo-Baker, S. (2013). Online training of TPACK skills of higher education 
scholars: A cross-institutional impact study. European Journal of Teacher Education, 36(4), 480-495. https://doi.org/10.1080/02619768.2013.801073

Rosenberg, J. M., \& Koehler, M. J. (2015). Context and Technological Pedagogical Content Knowledge (TPACK): A Systematic Review. Journal of Research on Technology in Education, 47(3), 186-210. https://doi.org/10.1080/15391523.2015.1052663

Sergis, S. E. (2014). From Teachers' to Schools' ICT Competence Profiles. Digital Systems for Open Access to Formal and Informal Learning, (July), 307-327.

Sumantri, M. S., Prayuningtyas, A. W., Rachmadtullah, R., \& Magdalena, I. (2018). The Roles of Teacher-Training Programs and Student Teachers' Self-Regulation in Developing Competence in Teaching Science. Advanced Science Letters, 24(10), 7077-7081. https://doi.org/10.1166/asl.2018.12412

Susanto, R., \& Rachmadtullah, R. (2019). Model of pedagogic competence development: Emotional intelligence and instructional communication patterns. International Journal of Scientific and Technology Research, 8(10), 2358-2361.

Susanto, R., Rozali, Y. A., \& Agustina, N. (2019). Development of pedagogical competency models for elementary school teachers: Pedagogical knowledge, reflective ability, emotional intelligence and instructional communication pattern. Universal Journal of Educational Research, 7(10), 2124-2132. https://doi.org/10.13189/ujer.2019.071010

Tamte, C., Enochsson, A. B., Buskqvist, U., \& Kårstein, A. (2015). Educating online student teachers to master professional digital competence: The TPACK-framework goes online. Computers and Education, 84(1), 26-35. https://doi.org/10.1016/j.compedu.2015.01.005

Turgut, G., Tunga, Y., \& Kisla, T. (2016). Technology Education in Preschool : An Applied Sample Lesson. International Journal on New Trends in Education and Their Implications, 7(1), 81-91.

Uerz, D., Volman, M., \& Kral, M. (2018). Teacher educators' competences in fostering student teachers' proficiency in teaching and learning with technology: An overview of relevant research literature. Teaching and Teacher Education, 70, 12-23. https://doi.org/10.1016/j.tate.2017.11.005

Wahyudin, D. (2016). A View on Teaching Philosophy in Curriculum Implementation at the Indonesia University of Education. SOSIOHUMANIKA, 9(2), 235-248.

Wang, F., Li, W., Mayer, R. E., \& Liu, H. (2018). Animated pedagogical agents as aids in multimedia learning: Effects on eye-fixations during learning and learning outcomes. Journal of Educational Psychology, 110(2), 250-268. https://doi.org/10.1037/edu0000221

Wegerif, R., \& Major, L. (2019). Buber, educational technology, and the expansion of dialogic space. AI and SOCIETY, 34(1), 109-119. https://doi.org/10.1007/s00146-018-0828-6

Wheelan, S. (2004). The Handbook of Group Research and Practice. New York, NY: Sage.

Widyasari, Rasmitadila, Asri Humaira, M., Rusmiati Aliyyah, R., Abdul Gaffar, A., \& Rachmadtullah, R. (2019). Preliminary study on the development of blended learning (BLM) model: based on needs analysis and learning independence. Journal of Physics: Conference Series, 1175, 012207. https://doi.org/10.1088/1742-6596/1175/1/012207

Woofter, S. (2019). [Book Review]: Building Equity: Policies and Practices to Empower All Learners. American Journal of Qualitative Research, 3(1), 136-139. https://doi.org/10.29333/ajqr/5815

Yong, S. T., Gates, P., \& Chan, A. T.-Y. (2019). Similarities and Differences in Learning of Metacognitive Skills. International Journal of Game-Based Learning, 9(1), 1-14. https://doi.org/10.4018/IJGBL.2019010101 
Yousafzai, A., Chang, V., Gani, A., \& Noor, R. M. (2016). Multimedia augmented m-learning: Issues, trends and open challenges. International Journal of Information Management, 36(5). https://doi.org/10.1016/j.ijinfomgt.2016.05.010

Zare, S. (2018). Virtual Coexistence in a Persian Diasporic Weblog Community. Journal of Ethnic and Cultural Studies, 5(2), 77-88. 